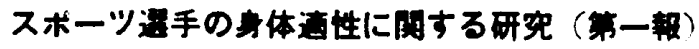

(6) ラクビー业手の其体过性について

東京都记台東商業高校 ○银 村 洁 司

日本体育大学 棉井永寿
日本体充大学 金子 正
日本体育大学 越智三 王

1) 研究の意義・目的

ラクビー澱手の身体睻を行い，その適件を究明する ために、これを分析研究した。また他の画目と比較し、 その差異を明らかにしようとした。

\section{2) 被験者の避定}

関東ラグビー $\mathrm{A}$ ブロックの $\mathrm{N}$ 大学チーム. 正選括 15 名, 補欠1名. 連手の競技歴は平均的 5 作。

3）湘定年月日

昭和 35 年 9 月 10 日

則定埸所 $\mathrm{N}$ 大学

湘定時間 午後 $4.00 \sim 6.00$

4) 揤定の結果

身体湘定にあたつては, 形態, 機能, 能力の各種目に ついて行つたが，表にその一部を提载. 他は省略.

5) 結果の考察

(a)各スポーツ恄目盖手とラグビー通手の比較形態的に は肩巾をはじめ胸囲、腰囲、丝明等が大であるが，邲閒に ついては他の稙目の㩔手に比較し特に優れているとは云 えない。

機能的測面では背勒力，握力が柔道や陸上選手上共に

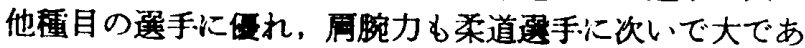
つた，即ち等力が非常に強い。

理動能力においては50人ートル聅走は陸上競技選手 と共に優れているが，垂淔跳をはじめとする他の能力は 一般に劣つていた。特に腕方，伏卧腕屈伸，サイドステ ツプ, 平衡性等は低い值を示した。

これを総括すると(1)形態的には柔道避手と共に他種目 の运手より優れ，(2機能的面で筇力が非常に強い，(8運 動能力では $50 \mathrm{~m}$ 疾走が最も明らかな特性で，その他は 全般に劣つていると考えられる，

(b)個人的考察

$\mathrm{N}$ 大学ラクビー・チームの中で最む技術的に但秀で あるといわれる D 避手（スクラム・ハーフ）と P 選乎 (スリークオータ)について，まず D避手は身長は低い が肩巾が大きく，譏能面では息こらえ能力が最も優れて

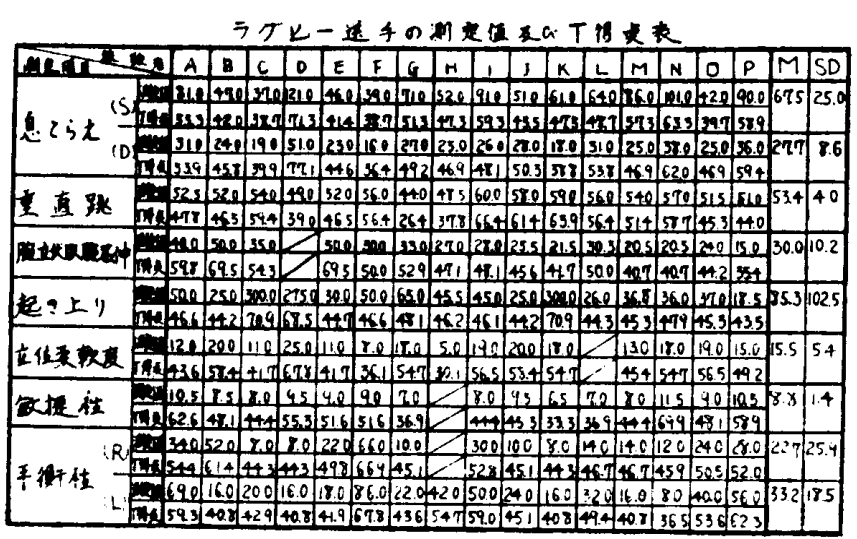

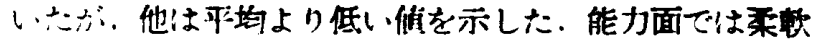
化，持久力，起き与り，サイドステッブに優れていた。

$\mathrm{P}$ 選手は胸囲がさいが身長は最も高い，機能面では大 きな值を示していたか，他の項目は全て平均値より低 い. 能力面においてはサイト゚ステップ。平衡性の他は一 般に少つていた。

次に D，P 選手に次いで找術か優れているといわれる A 選手 (ヘックロ一)，C 選手(ハックヒンター)，J 選手（七ンター）、をみると、A はこのチームで最す身 長が低いか：胸囲，大蛪用が大きく，身長の割に体重が 方る、機能面では㲜力をはじめ息こらえ能力等全般的に 優れていた，能力的面についても腕六伏卧腕屈伸，平衡 性，サイドステッフが優狆ていた，C为同様に身長は低 く，機能的面においては起き上り，持久力，腕立伏卧脕 屈伸が非常に優れていた。またポイント・ダッターとい われる丁選手は形態的には特に優れている方ではなく， 機能面においても条項目が平均值を下まわる。しかし $50 \mathrm{~m}$ 宛走をはじめとする能力面が非常に優れていた。

次にこのチームの補欠である B 選手と技術的にあま り传秀とはいえないＥ，H 選手等をみると 形態的には 侵秀選手に劣らないが，機能及び能力面についてては全般 に劦つていた，特に機能面では，その差は顥著に現われ た.

これを総括すると、補欠クラスの選手も偍秀者む(1)形 態的には明白な差がなかつたが(2機能及び能力面におい、 ては，優秀選手性に優れているむのをいくつか持つて いた。

6) 結 論

以上の考察により，ラグビー選手の身体的特致は采 道, 体操競技, バレーボール，陸上競技の選手に比較し

(1)形態的には有巾、頸囲，腰囲等の巾及び，周囲が大 であると共に，体重が重い。

(2)機能面及び能力面では $50 \mathrm{~m}$ 疾走, 胎力以外に全股 に劣つていた。

(2また個人的には传秀遥手は機能及び能力面の 項目 で, 特にいくつかのものに優れていたがそれに刘して補

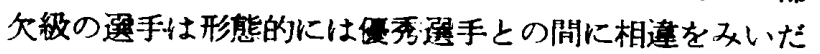
せなかつたが，機能、能力については全般に劣つてい、 た.

この他の特筫，ことに呼吸，循環器官の適性について は現在までのところ秥論できないので，次の報告にゆず ることにした．第二報に筋力指数をはじめ，適性が琶め られると思われる特留の適性指数を算出し、それによつ て選手嚄成，トレーニンク，コーチング等に資するもの たらんとナる次第である。

問 経訝作数何作以上の花在调查刘象にしたか。

$$
\text { (防人・渡边) }
$$

答平均こ分，最低る年〜フ件の日体止ラグビー一軍 连度 